\title{
Firefly Algorithm Based PID Controllers for Automatic Load Frequency Control in Different Power Systems
}

\author{
Manmadha Kumar Boddepalli, Prema Kumar Navuri
}

\begin{abstract}
The automatic load frequency control problem has been addressed in different power system areas such as single area, two area and three areas. Each area contain one thermal unit, one hydro unit and one gas unit. Initially, single-area three-unit system is addressed to analyze without and with PID controller for $10 \%$ of step load perturbation. After that, a two-area six-unit and three area-nine-unit systems are acknowledged and analyzed the effectiveness of PID controller. At last, capability of the proposed controller is assessed with a random step load disturbance. The total study was taken up in MATLAB/SIMULINK environment.
\end{abstract}

Keywords : PID Controller, Step load, Random load, Automatic Load frequency Control, Firffly Algorithm.

\section{INTRODUCTION}

Automatic Load frequency Control is the origin to numerous progressed concepts in the power system control. Interchange of tie line power to all the control areas are inter connected by the transmission lines to take the responsibility in the control of power system.

The major role of every control area is to generate enough power according to the demand in load, by its own generating location or purchasing the power from nearby control areas which are interconnected to each other. In the single area power system, it should not be possible to meet the excess load at the same time reliability issues will arise. To overcome this problem there is a need of interconnection of two or more power systems to serve the connected load, however each area may comprise of one or more number of generating units.

Several researchers have studied the concept of Automatic Load Frequency Con-trol. Puja Dash et al. [1] has studied about a multi area power system which is cascaded PD-PID controller. Its dynamic behavior was evaluated with PI and PID controllers and concluded that cascaded PD-PID controller exhibits a better result than the PI and PID controllers. In [2] Yogendra Arya and Narendra Kumar have used two areas with an AC/DC parallel connection to regulate proposed PI controller. The PI regulator shows superiority in craziness-based particle swarm optimization and hybrid bacterial foraging optimization algorithm-particle swarm optimization (hBFOA-PSO) algorithms. Proportional-Integral regulator with Differential Evolution
(DE) algorithm has been acknowledged with CPSO optimized PI controller by Banaja Mohanty et al. in [3]. Their analysis reviles that DE based PI controller shows the better performance. In [4] Rabindra K Sahu et. all has proposed a controller, in deregulated environment, with Modified Integral Derivative (MID) for multi-area multi-source system to conclude the effectiveness of hDEPS optimized MID controller exhibits over I and ID controllers. In ref. [5-6], the authors acknowledged FA based PID controller in two area power system which exhibits its ability when compared to other classical controllers. Ali et al. [9] have proposed BFOA optimized PID controller for two area AGC power system and concluded the proposed controller exhibits improved performance over ZA based PID controller and GA based PID controller. Authors in [7] have implemented BFOA based PI controller and revealed that the acknowledged configuration is superior against a conventional controller and GA based PI controller.

\section{MATERIAL AND METHOD}

In this paper, three units are considered where first one is Thermal power plant with reheat turbine, second unit is hydro power plant with governor and the third unit is gas turbine power plant. Figure 1 gives the considered PID controlled two area system. Similar systems are considered in the remaining two addressed systems. To find the objective function of Integral Time multiplied Absolute Error (ITAE), Firefly Algorithm (FA) has been studied. It is employed to tune the optimal values of the PID controller presented in Table 1in all the three studied power systems.

Table 1. PID controller Optimal values

\begin{tabular}{clcc} 
& \multicolumn{3}{c}{ Optimal values of PID controller } \\
\cline { 2 - 4 } Single & $\mathrm{KP} 1=1.7869$ & $\mathrm{KP} 2=0.9316$ & $\mathrm{KP} 3=1.1217$ \\
\cline { 2 - 4 } Area & $\mathrm{K} 1=0.9889$ & $\mathrm{KI} 2=0.1356$ & $\mathrm{KI} 3=1.7953$ \\
\cline { 2 - 4 } System & $\mathrm{KD} 1=0.5771$ & $\mathrm{KD} 2=0.5381$ & $\mathrm{KD} 3=1.1884$ \\
\cline { 2 - 4 } Two & $\mathrm{KP} 1=1.7869$ & $\mathrm{KP} 2=0.9316$ & $\mathrm{KP} 3=1.1217$ \\
\cline { 2 - 4 } Area & $\mathrm{KI} 1=0.9889$ & $\mathrm{KI} 2=0.1356$ & $\mathrm{KI} 3=1.7953$ \\
\cline { 2 - 4 } System & $\mathrm{KD} 1=0.5771$ & $\mathrm{KD} 2=0.5381$ & $\mathrm{KD} 3=1.1884$ \\
\cline { 2 - 4 } Three & $\mathrm{KP} 1=1.9134$ & $\mathrm{KP} 2=0.5440$ & $\mathrm{KP} 3=1.0540$ \\
\cline { 2 - 4 } Area & $\mathrm{KI} 1=1.8224$ & $\mathrm{KI}=0.4294$ & $\mathrm{KI} 3=1.6536$ \\
\cline { 2 - 4 } System & $\mathrm{KD} 1=0.2767$ & $\mathrm{KD}=0.8755$ & $\mathrm{KD} 3=1.7506$ \\
\cline { 2 - 3 } & &
\end{tabular}




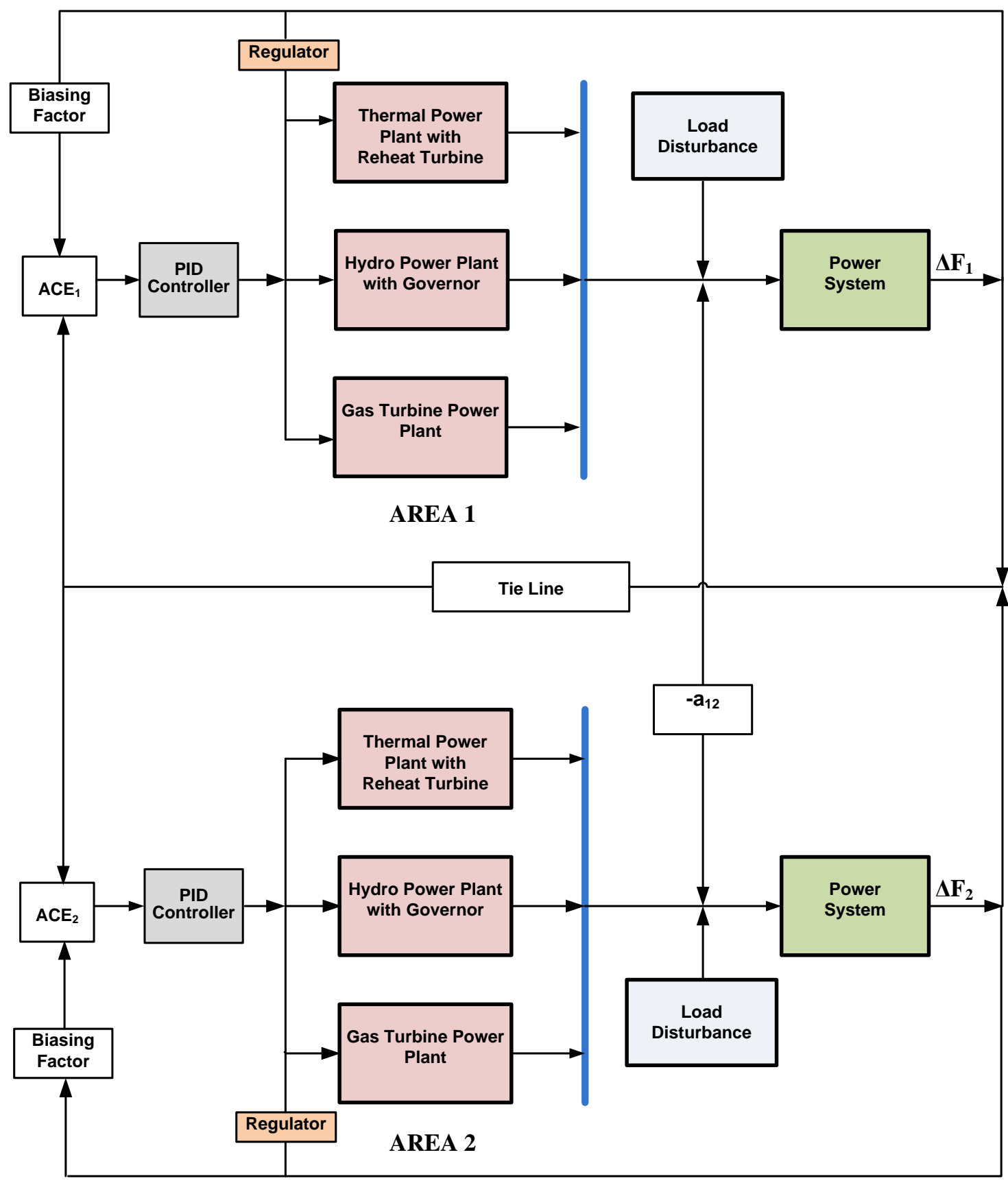

Figure 1: PID Controlled Two-area six-unit system

\section{FIREFLY ALGORITHM OVER VIEW}

A population-based algorithm called the Firefly Algorithm (FA), adopted by Yang [8]. They suggested that Fireflies are the insects which can be distinguished by producing flash light by a biochemical process called bioluminescence. For mating of two fireflies the flashing light will act as a signal. For proper design of FA the firefly's attractiveness is estimated from the brightness or intensity of light, represented as

$$
I(r)=I_{0} e^{-\gamma r}
$$

here $\gamma$ denotes the coefficient of light absorption $\mathrm{I}_{0}$ gives is the actual light intensity Attractiveness of a firefly is proportional to the intensity of light observed by nearby firefly can be represented as

$$
\beta=\beta_{0} e^{-\gamma r^{2}}
$$

here $\beta_{0}$ denotes attractiveness at a distance $r=0, r$ gives distance between two fireflies.

Absorption coefficient of the firefly is given by

$r_{i j}=\left\|s_{i}-s_{j}\right\|=\sqrt{\sum_{k=1}^{k=n}\left(s_{i k}-s_{j k}\right)^{2}}$

here $n$ is the dimensionality. $\mathrm{i}^{\text {th }}$ firefly's movement is attracted to another firefly $\mathrm{j}$ which has more attractiveness. 
In this study $\alpha, \beta$ and $\gamma$ values chosen as $0.5,0.4$ and 0.5 respectively. The tuned control parameters are taken for a maximum generation of 100 and the number of fireflies taken in this analysis is 6.

\section{RESULT ANALYSIS}

Dynamic responses the addressed single area three-unit, two area six-unit system and three area nine-unit systems have been observed and the each area has been shown respectively in the Figure 2 to Figure 5. In all the three cases the responses have been observed by $10 \%$ disturbance in step load.

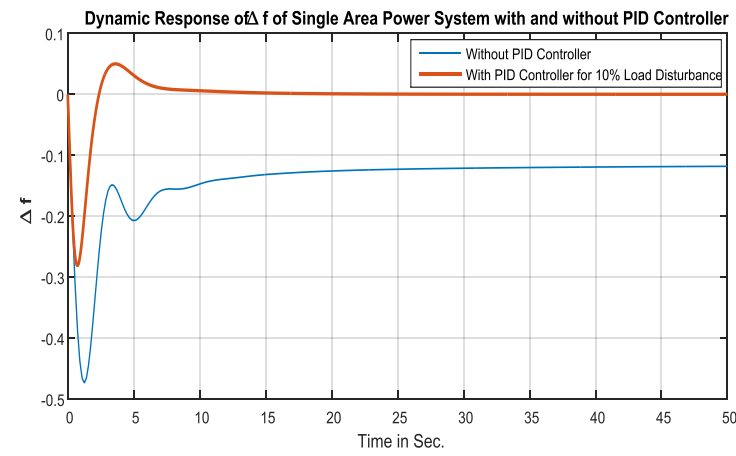

Fig. 2 Dynamic response of $\Delta \mathrm{f}$ in single-area system

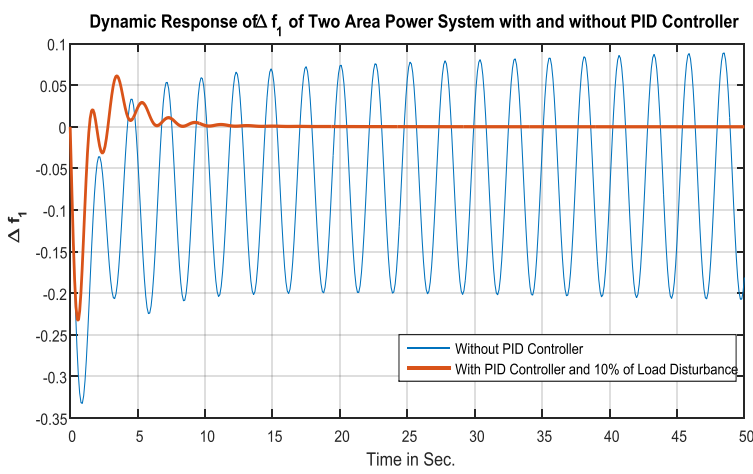

Fig. 3 Dynamic response of $\Delta \mathrm{f}_{1}$ in two-area system

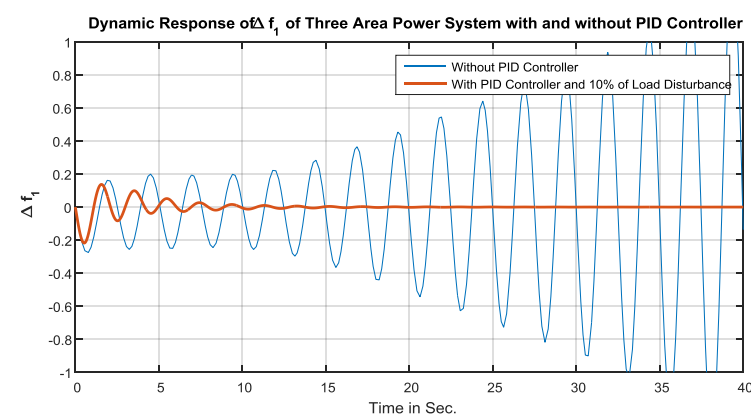

Fig. 4 Dynamic response of $\Delta \mathrm{f}_{1}$ in three-area system

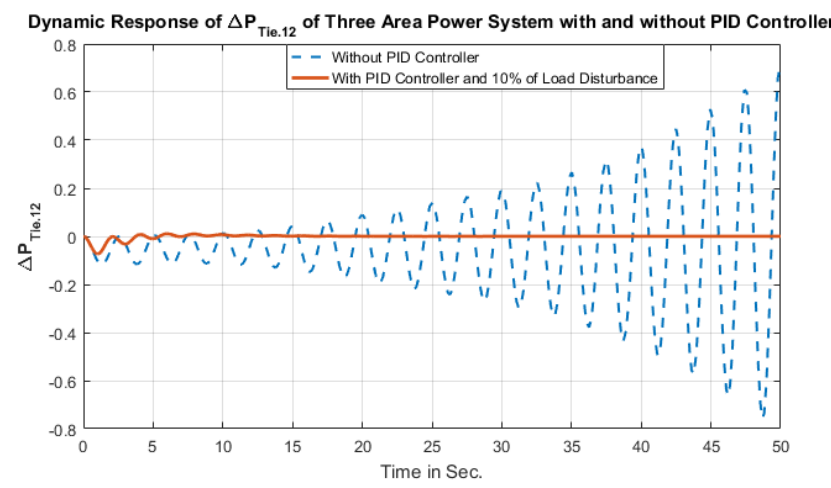

Fig. 5 Dynamic response of $\Delta \mathrm{P}_{\text {Tie.12 }}$

The performance index values have been tabulated by Table 2 with the band of $2 \%$ in single-area three unit system, where as Table 3 indicates the information of two area-six unit system and Table 4 gives the performance index of three-area nine unit system.

Table 2. Single Area Three Unit Power System

\begin{tabular}{ccccc}
\hline & & $\begin{array}{c}\text { Peak } \\
\text { Undershoot }\end{array}$ & $\begin{array}{c}\text { Peak } \\
\text { Overshoot }\end{array}$ & $\begin{array}{c}\text { Settling Time } \\
\text { (Sec.) }\end{array}$ \\
\hline \multirow{2}{*}{$\Delta \mathbf{f}$} & $\begin{array}{c}\text { Without PID } \\
\text { Controller }\end{array}$ & -0.4735 & -0.1485 & Unstable \\
\cline { 2 - 5 } & $\begin{array}{c}\text { With PID } \\
\text { Controller }\end{array}$ & -0.2812 & 0.0499 & 15.45 \\
\hline
\end{tabular}

Table 3. Two Area Six Unit Power System

\begin{tabular}{rcccc}
\hline & & $\begin{array}{c}\text { Peak } \\
\text { Undershoot }\end{array}$ & $\begin{array}{c}\text { Peak } \\
\text { Overshoot }\end{array}$ & $\begin{array}{c}\text { Settling Time } \\
(\text { Sec. })\end{array}$ \\
\hline$\Delta \mathbf{f}_{1}$ & $\begin{array}{c}\text { Without PID } \\
\text { Controller }\end{array}$ & -0.3322 & -0.0361 & Unstable \\
\cline { 2 - 5 } & $\begin{array}{c}\text { With PID } \\
\text { Controller }\end{array}$ & -0.2321 & 0.0206 & 11.6 \\
\hline$\Delta \mathbf{f}_{\mathbf{2}}$ & $\begin{array}{c}\text { Without PID } \\
\text { Controller }\end{array}$ & -0.3152 & 0.0528 & Unstable \\
\cline { 2 - 5 } & $\begin{array}{c}\text { With PID } \\
\text { Controller }\end{array}$ & -0.1591 & 0.0369 & 12.95 \\
\hline \multirow{3}{*}{$\Delta \mathbf{P}_{\text {Tie.12 }}$} & $\begin{array}{c}\text { Without PID } \\
\text { Controller }\end{array}$ & -0.0623 & -0.0041 & Unstable \\
\cline { 2 - 5 } & $\begin{array}{c}\text { With PID } \\
\text { Controller }\end{array}$ & -0.0361 & -0.0058 & 12.15 \\
\hline
\end{tabular}


Table 4. Three Area Nine Unit Power System

\begin{tabular}{|c|c|c|c|c|}
\hline & & $\begin{array}{c}\text { Peak } \\
\text { Undershoot }\end{array}$ & $\begin{array}{c}\text { Peak } \\
\text { Overshoot }\end{array}$ & $\begin{array}{c}\text { Settling Time } \\
\text { (Sec.) }\end{array}$ \\
\hline \multirow{2}{*}{$\Delta \mathbf{f}_{1}$} & $\begin{array}{l}\text { Without PID } \\
\text { Controller }\end{array}$ & -0.2750 & 0.1620 & Unstable \\
\hline & $\begin{array}{l}\text { With PID } \\
\text { Controller }\end{array}$ & -0.2175 & 0.1375 & 19.14 \\
\hline \multirow{2}{*}{$\Delta \mathbf{f}_{2}$} & $\begin{array}{l}\text { Without PID } \\
\text { Controller }\end{array}$ & -0.1195 & 0.0375 & Unstable \\
\hline & $\begin{array}{l}\text { With PID } \\
\text { Controller }\end{array}$ & -0.0715 & 0.0338 & 16.33 \\
\hline \multirow{2}{*}{$\Delta \mathbf{f}_{\mathbf{3}}$} & $\begin{array}{l}\text { Without PID } \\
\text { Controller }\end{array}$ & -0.0995 & 0.0115 & Unstable \\
\hline & $\begin{array}{l}\text { With PID } \\
\text { Controller }\end{array}$ & -0.0525 & 0.0159 & 9.45 \\
\hline \multirow{2}{*}{$\Delta \mathbf{P}_{\text {Tie.12 }}$} & $\begin{array}{l}\text { Without PID } \\
\text { Controller }\end{array}$ & -0.1172 & 0.0008 & Unstable \\
\hline & $\begin{array}{l}\text { With PID } \\
\text { Controller }\end{array}$ & -0.0730 & -0.0010 & 15.96 \\
\hline \multirow{2}{*}{$\Delta \mathbf{P}_{\text {Tie.13 }}$} & $\begin{array}{l}\text { Without PID } \\
\text { Controller }\end{array}$ & -0.0078 & 0.0240 & Unstable \\
\hline & $\begin{array}{l}\text { With PID } \\
\text { Controller }\end{array}$ & -0.0038 & 0.0158 & 7.08 \\
\hline \multirow{2}{*}{$\Delta \mathbf{P}_{\text {Tie.23 }}$} & $\begin{array}{l}\text { Without PID } \\
\text { Controller }\end{array}$ & 0.0009 & 0.0181 & Unstable \\
\hline & $\begin{array}{l}\text { With PID } \\
\text { Controller }\end{array}$ & 0.0006 & 0.0108 & 3.85 \\
\hline
\end{tabular}

Furthermore the three-area system is also tested with a load pattern shown in Figure 6 called Random step load, subjected to that the variation in area-1 frequency gives in Figure 7.

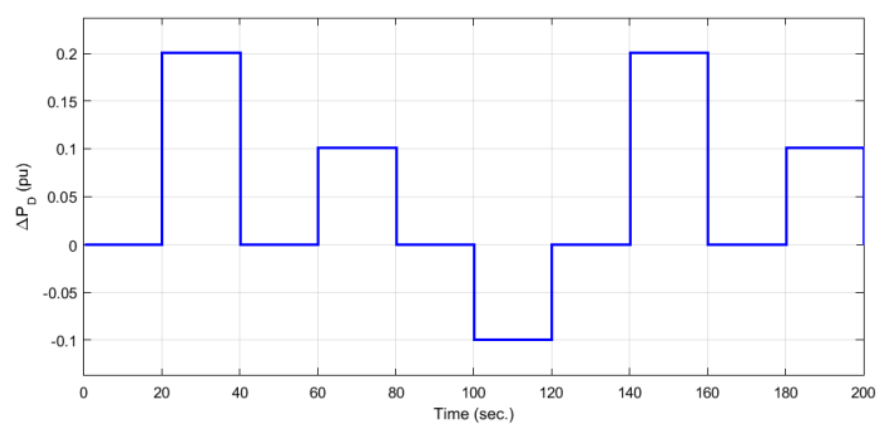

Fig.6 Random step load patter

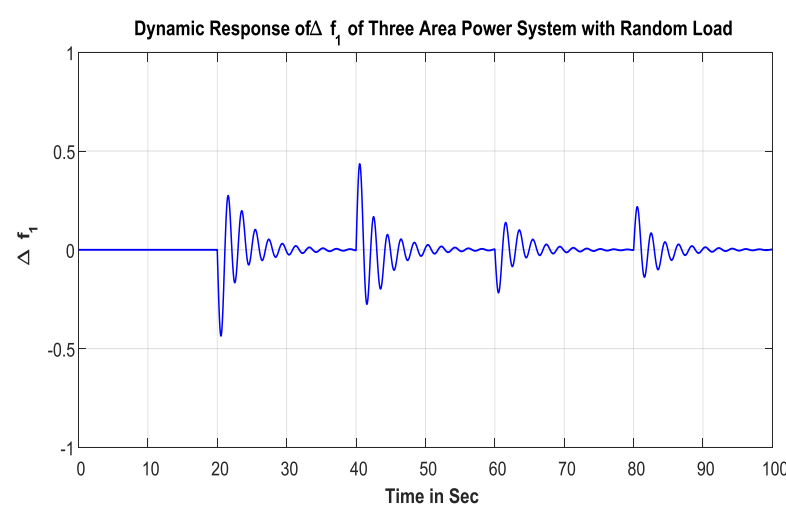

Fig.7. Dynamic response of $\Delta \mathrm{f}_{1}$ in area-1 with random load

\section{CONCLUSION}

In this paper, Proportional - Integral - Derivative controller has addressed in the Automatic Load Frequency Control problem in a single-area three-unit system, two-area six-unit system and three-area nine-unit systems. The comparative analysis was made for power system of single, two and three area power systems with and without PID controllers. After that, all the three systems were analyzed with and without PID controller. The corresponding performance index values are tabulated and effectiveness of the system is studied with and without PID controller. Furthermore random load is considered to study three-area-nine-unit system.

\section{REFERENCES}

1. Puja Dash, Lalit Chandra Saikia, Nidul Sinha. Automatic generation control of multi area thermal system using Bat algorithm optimized PD-PID cascade controller. Electrical Power and Energy Systems 68 2015: 364-372.

2. Yatin Sharma, Lalit Chandra Saikia. Automatic generation control of a multi-area ST - Thermal power system using Grey Wolf Optimizer algorithm based classical controllers. Electrical Power and Energy Systems 73; 2015: 853-862

3. Banaja Mohanty, Sidhartha Panda, P.K. Hota. Differential evolution algorithm based automatic generation control for interconnected power systems with non-linearity. Alexandria Engineering Journal, 2014: 53 , 537-552.

4. Rabindra Kumar Sahu, Tulasichandra Sekhar Gorripotu, Sidhartha Panda. A hybrid DE-PS algorithm for load frequency control under deregulated power system with UPFC and RFB. Ain Shams Engineering Journal, 6:2015: 893-911.

5. Rao, B. Venkateswara, et al. "Optimal power flow by Newton method for reduction of operating cost with SVC models." 2009 International Conference on Advances in Computing, Control, and Telecommunication Technologies. IEEE, 2009.

6. Mn Borhan,'Design Of The High Speed And Reliable Source Coupled Logic Multiplexer",Journal of VLSI Circuits And Systems 1 (01), 18-22,2019 
7. Yuvaraj, d., Rojinraju, n.Aravindaswin, Krishnan.k, and Rsteni Reyas. "Design Of Lcu For Reverse Air Bag House In Cement Industry." international journal of communication and computer technologies 7.supplement 1 (2019), 30-32. print. doi:10.31838/ijccts/07.sp01.07

8. Ali, E. S., and S. M. Abd-Elazim. Bacteria foraging optimization algorithm based load frequency controller for interconnected power system. International Journal of Electrical Power \& Energy Systems 33.3 (2011): 633-638.

9. Yang XS. Nature-Inspired Metaheuristic Algorithms, UK: Luniver Press, 2008.

10. Ali, E. S., and S. M. Abd-Elazim. BFOA based design of PID controller for two area Load Frequency Control with nonlinearities. International Journal of Electrical Power \& Energy Systems 51 (2013): 224-231.

11. O. I. Elgerd, Electric Energy Systems Theory: An Introduction, 2nd Ed New Delhi: Tata McGraw-Hill Publishing Company Ltd., ch. 9, 2004

12. D. P. Kothari, and I. J. Nagrath, Modern power system analysis. New Delhi: Tata McGraw-Hill Publishing Company Ltd., ch. 8. 2003.

13. Hadi Saadat, Power system analysis. USA: McGraw-Hill; 1999. 